\title{
Yasmine Char, La main de Dieu
}

\section{Veronica Amadessi et [veronica amadessi]}

\section{(2) OpenEdition}

\section{Journals}

\section{Édition électronique}

URL : http://journals.openedition.org/studifrancesi/6476

DOI : 10.4000/studifrancesi.6476

ISSN : 2427-5856

\section{Éditeur}

Rosenberg \& Sellier

\section{Édition imprimée}

Date de publication : 1 novembre 2010

Pagination : 605

ISSN : 0039-2944

\section{Référence électronique}

Veronica Amadessi et [veronica amadessi], « Yasmine Char, La main de Dieu », Studi Francesi [En ligne], 162 (LIV | III) | 2010, mis en ligne le 30 novembre 2015, consulté le 10 janvier 2021. URL : http:// journals.openedition.org/studifrancesi/6476 ; DOI : https://doi.org/10.4000/studifrancesi.6476

\section{Ce document a été généré automatiquement le 10 janvier 2021.}

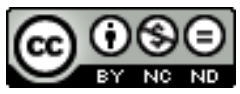

Studi Francesi è distribuita con Licenza Creative Commons Attribuzione - Non commerciale - Non opere derivate 4.0 Internazionale. 


\section{Yasmine Char, La main de Dieu}

Veronica Amadessi et [veronica amadessi] 


\section{RÉFÉRENCE}

YASMINE CHAR, La main de Dieu, Paris, Gallimard, 2008, pp. 121.

1 Écrivain et dramaturge libanaise, Yasmine Char publie un court roman où se mêlent l'amour pour un homme et l'amour pour une famille atypique, dans le cadre de la guerre civile qui a ensanglanté le Liban pendant quinze ans. En partant de quelques données autobiographiques (la mère française, les études de lettres), le centre du récit devient la guerre, élément absurde qui bouscule le destin de la jeune fille à la robe verte, car toute action normale en temps de paix assume pour elle des proportions incontrôlables: aller au lycée, marcher dans les rues, tomber amoureuse, tout se transforme en une occasion de mort. Dans ce contexte, l'amour se lie inévitablement au conflit et se confond avec ce dernier dans la personne de l'amant, qui est en réalité un franc-tireur. L'histoire, racontée par séquences, n'est pas coupée par la subdivision en chapitres, les blancs typographiques étant les seuls éléments qui permettent de saisir le changement de point de vue.

2 Si la dérogation à la règle semble être le fil conducteur de tous les épisodes, les descriptions et le récit des événements ont un goût cinématographique: le point de vue glisse en effet constamment de la première à la troisième personne, en un jeu de focalisations mixtes qui déroutent le lecteur. De plus, la fille trace un autoportrait qui mêle volontairement ses caractéristiques physiques avec celles de l'homme: visage d'une tueuse, corps asexué, attirance pour les armes, la narratrice semble nous dire que la guerre déstabilise la vision des êtres et des choses, et qu'elle renverse les valeurs et les règles à la base d'une société civile. Ce roman constitue un intéressant témoignage non seulement de la vie quotidienne des Libanais pendant la guerre, mais aussi de la complexité culturelle, religieuse et ethnique que constitue encore aujourd'hui le pays des cèdres. 